\title{
Regulating for Creativity and Cultural Diversity: The Case of Collective Management Organisations and the Music Industry
}

\section{Introduction}

In 1979, The Undertones released the song 'Teenage Kicks'; the band's singer was Feargal Sharkey. Thirty years later, Sharkey was Chief Executive of UK Music, an umbrella group representing the United Kingdom's music industry. And it was in this capacity that he wrote the Foreward to UK Music's (2010) Liberating Creativity policy statement:

Somewhere right now, in this country, a young person is scribbling on a scrap of paper or tapping on a keyboard, composing a song that will resonate far beyond the page. The industry may change, but that simple act of creativity remains, and will always remain, immortal and timeless.

Liberating Creativity captures a familiar dilemma, which Sharkey himself embodies. On the one hand, there is Sharkey-the-romantic who holds dear to the belief that there is something magical or mystical about the act of creativity, a moment in which an individual, or small group of individuals, are inspired to create. On the other hand, there is Sharkey-thelobbyist who argues for government intervention and investment in the name of 'creativity'. Sharkey is by no means alone in wanting to combine these two thoughts. But how they are combined, and to what effect, remains a nagging question for analysts of cultural policy.

We discuss some of the answers these analysts give below, but our main concern is with how we might assess the contribution to creativity of a particular institution - the Collective Management Organisation (CMO) - and with the public policy designed to regulate its performance. We also concentrate on a single sector of the creative industries: the music industry. We compare CMOs in various national settings in order to reveal the 
differences in their function and operation. We then consider the European Union's recent attempt - as part of the EU's Digital Single Market (DSM) strategy - to reform the regulation and role of CMOs. Our argument is, first, that CMOs are important, but neglected, intermediaries in the music industry, and that an insight into their importance can be garnered through comparative analysis. We then go on to show how the EU's reform strategy, itself premised on the importance of CMOs to the future of the digital creative economy, may affect Europe's music culture. Our intention is to indicate a) how cultural policy interventions may affect creativity and cultural diversity (two very different policy goals), and b) to engage with some of the theoretical and methodological issues raised by such an endeavour.

In what follows we begin by justifying our emphasis upon the $\mathrm{CMO}$, a justification that is couched both in terms of the neglect to which CMOs have been subject and the importance that they are assuming in a digital economy (Towse, 2013). This importance is recognized by the EU in its recent Directive on CMO reform (2014/26/EU), and by the recommendations of inquiries - like that by lan Hargreaves (2011) - for greater transparency, among other changes, in CMO practice.

Our concern is with an aspect of what might be deemed 'the institutional conditions of creativity'. This is not to deny the role of individual artists in the story, but rather to understand the institutional context in which they work, and to explain variations within and across countries in the forms and character of the art that emerges. To this extent, our concern is with the institutional politics of creativity, and specifically those of copyright and rights management.

For the purposes of this paper, Collective Management Organisations, which are also referred to as Collecting Societies, Authors Societies and Performing Rights Organisations, 
are typically to be understood as organisations that act on behalf of two sets of interests. The first are the composers of music and/or their publishers; the second are the broadcasters, public venues and other sites in which copyrighted works are played. CMOs serve the first by collecting and distributing the royalties earned by the right holders, and the second by enabling those works to be licensed for playing on the radio and in public spaces. CMOs have operated almost universally as national monopolies, providing a single port of call for licensees and an efficient system of data collection for right holders. While these two sets of interests predominate, a third set is in play: that of the public, which is seen to be the beneficiary of the resulting music culture.

\section{Background}

The general context for this paper is that of the digitization of the creative economy and the new problems, opportunities and players that it is heralding (see Hardy [2012] for an excellent survey). For the CMOs, the new economy is signalled by the emergence of streaming services and the issue of cross-border rights management. For the European Commission, the new era is embodied in its DSM strategy. The two are linked in the EU Directive (2014/26/EU) 'on collective management of copyright and related rights and multiterritorial licensing of rights in musical works for online use in the internal market'. This Directive is designed to align the collective management of rights with the new digital order. It rests on the assumption that CMOs are key to the future of a digital creative economy. It also assumes, as we also show, that competition between CMOs is vital to delivering an effective digital market.

The assumptions that underlie EU policy are themselves premised upon ideas about the relationship between creativity, cultural diversity and copyright. There is a growing 
literature on this relationship. It speaks of the ways in which copyright law serves to enhance or thwart creativity, and it debates whether copyright privileges certain types or forms of creative authorship over others (Burkhart, 2010; Fredriksson, 2014; Frith and Marshall, 2004; Gaines, 1991; McLeod and DiCola, 2011). Whatever the claim, the point is the same: copyright is understood to be linked - positively or negatively - to creativity. ${ }^{1}$ This literature - like the law itself - does not, for the most part, grapple with the question of what is meant by 'creativity', and how it might be evaluated. Rather, the authors are concerned to identify the ways in which artists come to benefit from, or clash with, the requirements of the copyright regime. For example, Kembrew McLeod and Peter DiCola (2011: 6) talk of 'how the law encourages some form of creativity and discourages others.' The question of what, independently of the interpretation of the courts, makes an act 'creative' or what defines 'creativity' is not their concern.

In one of the few sustained attempts to define and explain creativity, Keith Negus and Mike Pickering (2004) also discuss copyright's role in detail. They note that copyright was introduced to 'incentivise' creativity, by discouraging copying and rewarding the originating author. It was designed to provide a source of benefits to the creator and to the wider society that would prosper from the artist's creativity. But, as Negus and Pickering also note, to observe the intentions of copyright is not to describe its effects. Does copyright, they ask, actually reward those it was intended to benefit, whether the artist or the wider society? Have changes in the technologies of creativity (the capacity to fix and reproduce a work of art) and in the corporate interests allied with it (the culture/creative industries) radically altered copyright's role and its relationship to creativity?

\footnotetext{
${ }^{1}$ Or more accurately, 'originality', since the law is silent on creativity. With thanks to Ruth Towse for this point.
} 
In assessing changes to copyright and its effects on creativity, Negus and Pickering (2004: 63) set themselves against what they see as the 'unhelpful dichotomous terms' in which the debate is often framed: artists versus corporations; rich countries versus poor ones. Rather, they suggest that close attention needs to be given to the specifics of copyright and the ways in which it constitutes the possibilities (and the restrictions on them) faced by an artist, as well as the relationships that exist between artists and the many intermediaries who populate the 'copyright regime'.

The question this raises is how we might analyse and evaluate these multiple factors in the creative process. For this, we need to turn to a different literature, one not concerned with copyright, but rather with industrial organization theory and the market in music.

\section{Explaining and evaluating innovation in music}

There are, of course, many different approaches to explaining cultural innovation. One of the most familiar is what Stanley Lieberson (2000) has called 'reflection theory'. This is the idea that creativity and innovation are generated by the wider social and political context in which the artists reside. Such an account can, in the case of The Beatles, be found in Mark Lewisohn's (2013) compendious biographical history of the band, in which the context provided by the city of Liverpool and the conditions of the post-war economy loom large. It is also apparent in many accounts of the rise of punk in the 1970s as a response to the economic downturn (see Hebdige, 1979; Savage, 1991). For Lieberson (2000: 273), however, there are limits to reflection theory, revealed its tendency to ignore 'the role of internal mechanisms and therefore the fact that changes occur even where external conditions remain constant.' 
An example of the 'internal mechanism' approach is provided by other attempts to 'explain' The Beatles. Greg Clydesdale (2006: 138), for example, has argued that The Beatles' success was a direct product of their competitive environment: 'In the case of The Beatles, competition-based incentives, such as outperforming the competition, enhanced innovation.' By contrast, Simon Frith (1988) has contended that The Beatles' creativity was enabled by the very absence of competition. The fact that the BBC was free of pressure from advertisers enabled it to provide a protected space in which The Beatles could experiment and innovate in public. What Frith and Clydesdale have in common is an assumption that creativity is a product of an infrastructure rather than a cultural, social or economic climate.

Such thoughts have been the focus of a particularly resilient strand of music scholarship. From the 1970s, music scholars have asked: under what market or institutional conditions do we get innovation in popular music? To answer such a question, they had a) to establish a measure of 'innovation'; and b) to isolate and identify the mechanism responsible for it.

The first systematic answer was provided by the sociologists Richard Peterson and David Berger (1975). By examining the turnover in singles appearing in the US top 10, and mapping this onto the structure of the music market, they concluded that market competition was indeed the driver of musical change and innovation. Their initial foray led to a spate of responses from other researchers, and by follow-up studies from Peterson and his colleagues. These are schematically documented in Table 1, in which we trace both the measure of musical innovation used and the factors associated with it. As can be seen, for much of the history of this literature the basic framework remained unaltered. Market structure was mapped onto innovation. Researchers varied only to the extent that their focus was on albums, rather than singles, or to the extent that 'innovation' was understood 
in terms of stylistic devices, rather than in terms of the turnover of artists in the charts. A more significant variation from the original Peterson and Berger approach was represented by a shift away from competition between independent companies towards the internal structure of music industry corporations and the degree of latitude allowed to corporate executives (Negus, 1999).

[Table 1 about here]

With this latter move, questions began to be raised about the appropriate methodology by which to connect innovation to industrial change (Christanen, 1995), and about what constituted relevant innovation - was it just 'novelty' or was it changes in the representation of women or African Americans that mattered (Dowd, 2004; Lena, 2006)? In the same spirit, questions were asked about which other market actors - retailers and broadcasters - were to be included (Fox, 2005), or of what role was played by the internet (Waldfogel, 2012). And even as these revisions were made, the focus remained heavily dependent on the charts as a measure of creative innovation and the US as the case study. Non-US studies were the exception (Christianen, 1995); and comparative studies almost non-existent.

Despite these later developments in approach and measurement, the conclusion of almost all these studies has been that innovation and diversity depend on competition. The more intense and open the competition the greater the innovation and diversity to be found in the resulting music. This conclusion does not seem to have changed with digitization, although the sophistication of the research certainly has (Ferreira and Waldfogel, 2013).

However, irrespective of this consensus, there are at least three limits to this research tradition. These go beyond the focus on a particular genre or form of music. They relate to the relatively (again, it varies) simplified model of the market being applied. 
Typically, the market is understood to involve firms, artists and audiences/fans. While there is much to be learnt from the terms under which the firms compete, the 'industry' is narrowly conceived as comprising recording companies or record labels only, and makes little or no acknowledgement of the other 'industries' involved - ie broadcasting, publishing and live performance (Cloonan and Williamson, 2007). One way of refining an understanding of the conditions of creativity, therefore, is to examine the role of these intermediaries in the market. This is acknowledged by one of the founders of the tradition we have been discussing, Richard Peterson (1990), who in his article 'Why 1955?' locates the origins of rock'n'roll in the concatenation of legal, economic and institutional processes of the time.

Another refinement is to introduce a comparative element. This is to counter a second limitation. Most of the research listed in Table 1, as we have noted, employs a single, national case study. A comparative analysis of the performance of different national industries would allow us to hypothesise about the factors affecting the performance of those industries, and to identify the contribution made by particular intermediaries.

The final limitation stems from the terms applied to the analysis. Typically, the music market is assessed in terms of 'innovation', rather than 'creativity', and the two terms may not be synonymous. Indeed, there is a third term which emerges - implicitly or explicitly - in the later studies, and this is the notion of 'cultural diversity'. Although it shares a family resemblance to both creativity and innovation, cultural diversity may have other, quite different connotations and policy implications (see, Street, 2011, Schlesinger, 2013, or Hesmondhalgh et al, 2015, for an overview).

In an attempt to counter these limitations, and to get an indication of how intermediaries may contribute to creativity, we conducted a comparative analysis of the role 
played by Collective Management Organisations in a number of territories, and in doing so we tried to identify the contribution made to (or intended for) such policy goals as cultural diversity or creativity. CMOs, we suggest, are key intermediaries, particularly in a digital era. We present findings from the comparative study, together with illustrative cases, to show how CMOs differ in the contribution that they aim to make to their respective national music cultures. We then consider the impact of the EU's initiative to consolidate and harmonize the regulation of CMOs. We argue that just as CMOs may have a significant role in the creation of national music cultures, so the EU's reforms may (adversely) affect creativity and cultural diversity across Europe.

\section{The role and reform of Collective Management Organisations}

In the literature on innovation and the music industry very little attention is given to the role of the CMOs. Indeed, they are neglected too in the general literature on the music industry, even where the focus is on the specific effects of digitalization (see, for example, Hardy, 2012; Jones, 2012; and Wikstrom, 2009; exceptions include Haunss, 2013; Laing, 2004; Wallis, 2004; Wallis et al, 1999).

While the CMO may be overlooked in music studies, it has attracted the attention of legal and economics scholars (eg Kretschmer, 2005; Kreschmer et al, 2005; Towse, 2000a, 2000b, 2002, 2006a and 2006b; Handke and Towse, 2007; Hilty and Nerisson, 2013). It has also caught the notice of policy makers, in particular those who regulate competition. The $\mathrm{CMO}$ - as a national monopoly - has posed problems as to how it should be managed accountably so as to benefit rights holders and those who use their works (Towse, 2012). The $\mathrm{CMO}$ has also featured in the deliberations of national governments and transnational authorities which wish to advance the cause of the creative industries. There is a long 
history of European Commission, European Court of Justice and European Union scrutiny of CMOs and a slightly shorter one in the UK, evidenced most recently in the Hargreaves (2011) report and the subsequent work of the Intellectual Property Office (Laing, 2004; Ward, 2013). The main focus of the legal and economic literature and of the policy initiatives has been on rights and economic efficiency. Less attention has been devoted to other dimensions - most notably, the cultural value of what emerges from the copyright regime. This is our particular concern here.

Many - if not all - CMOs are committed to promoting social and cultural value. They are charged with contributing to the quality of the music culture of their territory. This is what Kretschmer (2005: 8) has called their 'solidarity rationale' - by which he means supporting domestic creators, the cross-subsidizing of small rights holders by larger ones, and 'discrimination between genres'. It can also take the form of a commitment to 'cultural diversity'. This ambition is shared by the EU. A version of the solidarity rationale features in the new EU Directive on the collective management of copyright. In the preamble to the Directive, the EU notes that previous Directives on copyright and related rights were designed to 'contribute to the development and maintenance of creativity' (recital 1), and goes onto argue that CMOs 'play, and should continue to play, an important role as promoters of the diversity of cultural expression' (recital 3).

So, to summarise, we have a general concern with the conditions under which creativity might be enabled to flourish, a literature that has, for the most part, neglected the particular contribution of the $\mathrm{CMO}$ to these conditions, and a policy agenda that imagines and expects such a contribution to be made. How might we analyse and evaluate the extent to which an intermediary - in this case, the $\mathrm{CMO}$ - contributes to creativity? 


\section{Evaluating the contribution of CMOs: from creativity to cultural diversity}

In analyzing the role of the $\mathrm{CMO}$ in fostering creativity, the first issue that arises is how 'creativity' features in the agenda and intentions of these organisations. This raises a very complex, controversial and long-running debate, and we can do no more than sketch its outlines (see Hesmondhalgh et al, 2015: 55-59; 97-100). The language chosen tends to be determined by the interests of those using it. Where the concern is market performance, the tendency is to use the language of 'innovation' and 'market choice'; where the focus is cultural policy, the key criteria are 'excellence' (Jowell, 2004) or 'cultural diversity' (UNESCO, 2005). The EU Directive itself, as we quote it above, moves from 'creativity' in recital one, to 'cultural diversity' in recital 3. These terms have, in fact, radically different implications for policy, and are associated with different institutions and interests.

Within key international bodies, notably the EU, the Council of Europe and UNESCO, the emphasis is increasingly upon 'cultural diversity' as a core value to which cultural policy is directed. The concern with cultural diversity might be viewed as a response to processes such as globalization, 'glocalisation' and 'McDonaldisation', each seen as containing a threat to national or ethnic identities and cultures (Nash, 2010). In its recent Consultation Document on European copyright policy, the EU makes explicit the connection between its various economic and cultural agendas. It says that for the EU copyright regulatory framework to be 'fit for purpose in the digital environment', it must 'support creation and innovation, tap the full potential of the Single Market, foster growth and investment in our economy and promote cultural diversity' (2013: 2).

While the language of 'creativity' and 'innovation' remains, it is increasingly evident that, in respect of the cultural values to be promoted in cultural policy, the core term is 'cultural diversity'. The first of the main principles subscribed to by the Council of Europe in 
matters of culture is respect of identity and promotion of cultural diversity and intercultural dialogue. This is linked by the Council to the protection of human rights and the promotion of (cultural) democracy. ${ }^{2}$

One of the key statements on cultural diversity is UNESCO's (2005). This refers to 'cultural activities, goods and services as vehicles of identity, values and meaning' and makes cultural diversity a necessary condition of other principles, most notably freedom of expression and communication. This is understood to require 'the ability of individuals to choose cultural expressions'. The principle of state sovereignty allows for states to protect the diversity of cultures within the nation. And the principle of equality is held to require 'equal dignity of and respect for all cultures, including the cultures of persons belonging to minorities and indigenous peoples.'

A commitment to cultural diversity is different from a commitment to cultural excellence. As Brian Barry (2001) has argued, there is no necessary connection between the two. Indeed, Barry suggests that they are incompatible, and that the one cannot be delivered by the other. Cultural diversity will not guarantee excellence, and vice versa. The issue is, then, which agenda is to be preferred. This is a matter of political argument and judgement (see Parekh, 2000). The EU, and those who place cultural diversity as a primary goal of cultural policy, are making a political choice. This judgement may not only entail a rejection of 'excellence' as a priority, but also of 'innovation'. 'Innovation' may neither entail excellence nor diversity; it may merely signify a new market option. The politics of this are too complex and fraught to be considered further here. We simply note that the selection of criteria by which to evaluate the ends of cultural policy is political in the same sense that

\footnotetext{
${ }^{2}$ Council of Europe statement on Values, available at: http://www.coe.int/en/web/aboutus/values
} 
different institutional forms will result in different cultural values and policies. By way of illustration of this, and of the role of CMOs in it, we compare the operation and regulation of collective rights management in several jurisdictions. Our question is simple: how do they differ in the contribution they seek to make to the conditions of creativity and cultural diversity?.

\section{Comparing CMOs and their role in the music industry}

European $\mathrm{CMOs}$ differ in their contribution to the music culture in their respective territories. Our focus here is on the 'solidarity' element of their role, and particularly the desire to improve the quality of culture, rather than simply to reward creative effort. GESAC, the European association of CMOs, states that most CMOs pursue an intensive cultural agenda and support many activities and events neglected by the market, i.e. demanding or risky repertoires (contemporary music, improvisation, poetry, etc.) and works created by young professionals. ${ }^{3}$ This begs the question as to how the CMOs do this, and what can be learnt through comparison between CMOs. We begin by comparing three specific individual CMOs: SACEM in France, PRS for Music in the UK and GEMA in Germany.

\section{Comparing CMOs (1): social and cultural contributions}

SACEM plays an active part in music making in France. It describes its own approach as 'three pronged' (SACEM website: http://www.sacem.fr/cms/site/en/home/creatorspublishers/cultural/cultural-initiatives_1). Firstly, it aims to support 'original creative work' across all music genres, then to give grants to assist live performances at concerts and

\footnotetext{
${ }^{3}$ See http://www.authorsocieties.eu/uploads/Modules/Library/rapport-benabou_gestioncollective-(2)-2.pdf
} 
festivals in France, and finally to provide assistance for training programmes to develop the professional skills of young artists. SACEM is actively committed to an agenda that promotes 'creativity' and cultural diversity, broadly understood. It embodies the 'solidarity' approach, and is proactively engaged with music-making in France.

SACEM's approach is, it should be noted, in accord with French state cultural policy more generally. Successive French governments have been at the forefront of support for what came to be called the 'cultural exception' in international trade relations, following the GATT treaty of the late 1940s (Looseley, 1995). Most recently, the exception argument has prevailed in the negotiations for a Transatlantic Trade and Investment Partnership between the EU and USA, when in June 2013 EU trade ministers agreed to exclude 'Audio-Visual services' from the talks (European Parliamentary Research Service, 2014). ${ }^{4}$ This international stance is paralleled by a range of domestic measures to support French cultural expression, including an airplay quota, limiting the radio exposure for nonFrancophone music, and laws to ensure that a proportion of the private copying levy or tax is spent on developing and promoting Francophone music artists, venues and recordings (Looseley, 2003). But while SACEM's activist role may accord with national policy, this does not detract from the fact of its activism. SACEM is regarded as an integral part of the delivery of that policy.

In contrast to France, the UK does not have an explicit cultural strategy or programme to enhance cultural diversity. The nearest equivalent is a paper from the Arts Council for England (nd), 'What is the Case for Diversity?', in which it is stated: 'since the 1970s, the Arts Council and those it funds have pursued various ways of increasing equality

\footnotetext{
${ }^{4}$ These could be reinstated, but only if all member states agree.
} 
in the arts, mainly by implementing measures under the umbrella term 'cultural diversity".

The expectation is that individual organizations will establish their own agenda.

PRS for Music, SACEM's UK equivalent, also presents itself as contributing to the nation's music culture, but what differentiates the two is the language (and its implicit assumptions) in which it explains it role. Here is PRS on the creation of its own Foundation:

Supporting new music has always been important to our members. In 1999, we launched an independent charitable foundation that has become the UK's leading funder of new music across all genres. The PRS for Music Foundation aims to stimulate and support the creation and performance of new music in the UK and motivate public debate about creative music-making through ground-breaking projects such as the New Music Award. (PRS website:

http://www.prsformusic.com/aboutus/ourorganisation/community/Pages/default.a $\underline{\mathrm{spx}})$

Although many of the specific interventions made by PRS are similar to those of SACEM, PRS couch their agenda in terms of 'new music', and the 'diversity' being sought is that between music genres or styles, rather than the national cultural identity that underpins the SACEM approach. ${ }^{5}$ PRS's emphasis on 'new' music opens up a different set of issues, if only because the adjective can be used to designate music that is either recent or innovative or both. The barriers that PRS identifies are less about cultural recognition and identity, and more barriers to entry into a market. Its Momentum Music Fund, jointly financed project with Arts Council England (ACE) (http://www.prsformusicfoundation.com/Funding/Momentum-

\footnotetext{
${ }^{5}$ See, by way of contrast, the Irish Music Rights Organisation (IMRO) which states that it is 'prominently involved in the sponsorship and promotion of music in Ireland' (IMRO website: http://www.imro.ie/about-imro/)
} 
Music-Fund), is designed to help financially 'artists and bands who are at a crucial point in their development, with the potential to significantly further their career within the next two years.' This suggests a very different form of intervention to that of its French counterpart.

In contrast to SACEM, PRS for Music does not seek to promote 'cultural diversity', as it was understood by SACEM or by the EU. This difference was further revealed in a dispute with an organization representing PRS members who create music in the Welsh language, the Welsh Music Publishers and Composers Alliance (WMPCA). The latter claimed that Welsh right holders were being inadequately rewarded for radio and television usage of their works. PRS for Music's response was that it operates a system of standard payments for music, 'irrespective of genre, language or other distinctions. ${ }^{6} \mathrm{PRS}^{\prime}$ 's position suggested a strong notion of equality that trumped claims based on 'cultural diversity'.

GEMA, the German CMO, is closer in disposition to SACEM than to PRS. It provides support for young musicians and runs a hardship fund (as well as health care and pensions) for all members. It is required to do so by German law. More importantly, for our concerns here, its legal obligations make explicit its commitment to cultural diversity. GEMA crosssubsidises between genres and provides tariff reductions for certain types of concerts (based on the type of music, not its language). It is required to promote culturally valuable works and activities. GEMA's commitment to these goals, unlike with SACEM or PRS, is a consequence of the legal obligations placed upon it.

\footnotetext{
${ }^{6}$ WMPCA then established its own $\mathrm{CMO}$, Eos, to negotiate directly with the $\mathrm{BBC}$, the main broadcaster of Welsh language music and other programming. The resulting impasse led to a hearing before the Copyright Tribunal.
} 
The three examples provided by SACEM, PRS and GEMA are illustrative of how $\mathrm{CMOs}$ conceive their role in relation to their respective national music cultures. The difference can be represented in purely economic terms. See Figure 1, where we plot spending of each $\mathrm{CMO}$ on their social and cultural agendas. However, as we have indicated, this tells only part of the story. The variations in the purpose attributed to these contributions are as significant, if not more so. The differences between the positions adopted by SACEM, PRS, and GEMA help to contribute to our understanding of how institutions and intermediaries may shape (or intend to shape) music culture.

\section{Comparing CMOs (2): interests and motivations}

In the previous comparisons we examined the declared policy aims of the CMOs. This, though, is only part of the story. We need also to consider the interests and incentives to which they are responding. In comparing these, we follow the example set by a number of other scholars (for example, Burke, 1996; Kretschmer, 2002; Rochalandet, 2003; Guibault \& Van Gompel, 2012). But where these others have tended to focus on the legal and regulatory framework, we have chosen to look at the sources and sizes of their income. Our assumption is that, in understanding the finances of CMOs, we will appreciate how a core aspect of their interests are formed and hence how their priorities are ordered. We have used the CMOs' websites and other published information to collect our data.

We begin with their income. Figure 1 plots the income (standardized to euro equivalents) received by the CMOs of France, the UK, Germany, Sweden (STIM), Spain 
(SGAE) and, by way of further comparison, the US (ASCAP). ${ }^{7}$ What is evident is that all but one (STIM) of our CMOs enjoy roughly equivalent income levels.

[Figures 2-6 roughly here]

Differences emerge, however, when we consider the sources of this income (i.e. how much derives from broadcasting as against streaming, and so on). Figures 3 and 4 show that there is considerable variation between those CMOs that rely on income from traditional forms of broadcasting and those that depend on online income. Variations are also evident in the income that derives from foreign sources (i.e. from a repertoire that is used outside their home country) and from live performance (see Figures 5 and 6). Finally, Table 2 documents the differences in administrative costs. These are important to members to the extent that income spent on administration is income not returned to right holders. Each of these variations affect the incentives and interests of the CMOs and of their membership. Those CMOs that rely on online income might be expected to act differently to those who remain wedded to traditional broadcasting. High administrative costs may be a sign of inefficiency, but they may also be indicative of a commitment to other, non-economic goals. This, in turn, may mean that the CMO works to the benefit of the less successful composer (who needs support) or works against the more successful one (who is deprived of royalty income).

[Table 2 about here]

These variations, and of course there are others to which we could refer, are illustrative of our general point. CMOs differ in ways that affect their interests. These

\footnotetext{
${ }^{7}$ It is important to note that STIM and ASCAP deal in performing rights only; GEMA, SACEM and PRS deal in licensing, performing and mechanical rights; SGAE and SACE manage music and audioviual rights. Our thanks to Frances Lowe of PRS for Music for drawing our attention to these differences.
} 
interests are key to how they act; they shape their incentive structure. This in turn will determine how they distribute their efforts in operation of the music market, in particular their relationship with the members and with the wider music culture. Our contention is that such comparisons are a crucial tool in any attempt to explore the role played by specific intermediaries in the creative life of a country (or region). Such comparisons are not easy to conduct, and are subject to debate and dispute, but they indicate how intermediaries are implicated in the fortunes and features of their respective markets.

\section{CMOs and Digital Single Market: the case of the EU Directive}

In this final section, we turn our attention to the European Commission's decision to reform the regulation of CMOs in order to achieve the goals of the Digital Single Market. This intervention, as we noted earlier, is premised on the assumption that CMOs matter to functioning of the European music market and to the goals that the market serves. Directive $(2014 / 26 / 14)$ is a major initiative designed to enable the management of rights to operate more effectively in the digital economy in which national borders no longer assume the role they did in the analogue era. It requires the creation of a system in which right holders may authorize any $\mathrm{CMO}$ to act on their behalf. CMOs are required to meet standards of governance and transparency that assuage misgivings about their monopoly status. They are, for example, required to provide information on deductions made for 'social, cultural and educational services' (Article 13(4)).

Beyond ensuring that CMOs observe particular governance criteria and meet standards that serve the economic interests of their members and users, the Directive also addresses the role of CMOs in promoting cultural diversity. It specifies this role in two ways:

a) 'enabling the smallest and less popular repertoires to access the market'; and b) 
'providing social, cultural and educational services for the benefit of their right holders and the public.' (ibid.)

In themselves, these aims appear to recognize a broader agenda than simply economic efficiency, and to be designed to enhance Europe's music culture through the good offices of the CMOs. However, Christoph Graber (2012) has argued that the Directive is not even-handed in its treatment of the goals it sets itself. According to Graber, the cultural agenda is marginalized, and indeed compromised, by the economic efficiency agenda. He contends that the Directive is

a) framed to favour right holders over users;

b) designed to promote competition between CMOs that will lead to a focus on the 'most lucrative' of music rights; and

c) likely to lead to the under-representation of 'less popular music and music in languages that are less widely-used.' (Graber, 2012: 8)

If Graber is right, the Directive and the new $\mathrm{CMO}$ order will adversely affect music culture in Europe by reducing its diversity.

This effect may be compounded by other developments in collective management. The status quo ante involved the granting of 'blanket' licenses on a national basis to broadcasters and other licensees for the whole of the global music repertoire, providing an opportunity for licensees to use items from even the most obscure music genres or national repertoires. In contrast, there is now a system of piecemeal cross-border licensing that enables licensees to get access to limited parts of the global repertoire by making agreements with new CMOs set up for this purpose (Towse, 2013). Thus, CELAS - a joint venture between EMI Music Publishing, PRS and GEMA (the German music CMO) - can license all the Anglophone pop songs published exclusively by EMI for online and mobile 
purposes. The temptation for licensees such as broadcasters and streaming companies is to license only this repertoire (and similarly lucrative ones) and to ignore the repertoire of other national languages. It is notable that in the US the courts have ruled against such selective practices (Complete Music Update, 21 July 2015).

Adolf Dietz (2014), another critic of the Directive, offers further grounds for suspicion. He argues that the Commission is insufficiently concerned for the cultural (as opposed to the commercial) role of the CMOs. He argues (2014: 11) that the European Parliament has shown much more interest in the cultural impact of copyright than has the Commission. The latter is more interested, he suggests, in matters of competition and antitrust, and that these do not necessarily serve the EU's commitment to creativity and cultural diversity. Dietz (2014: 14) contends that anti-trust rules operate negatively; they 'push the [collecting] societies to compete, which is not appropriate to the sector'. He worries (2014: 15-16) that one consequence of this will be the diminution of the social and cultural contribution made by CMOs.

Although Dietz (2014: 23) acknowledges that the Commission's line on the CMOs' social and cultural role softened during the passage of the Directive, he remains convinced that the European Parliament better expresses or represents the cultural interests of the European community. The Commission, he insists, is still 'aimed primarily towards the internal market and the European economy as a whole' (Dietz, 2014: 17). Such priorities, Dietz suggests, serve the interests of the larger CMOs and the repertoires for which they are responsible (see also Towse, 2012). While the Directive is formally seeking to counter this trend by making provision for the compulsory licensing of the 'less popular' music under certain circumstances, whether or not this will preserve the existing degree of cultural diversity in European music will not be known until several years hence. 
The tensions and questions raised by the Directive's critics stem from their understanding of the role of CMOs and of the goals to which they are required to work. The critics have doubts about the EU's own assumptions: that competition is key to creativity; and that competition between CMOs depends on the 'high standard of governance, financial management, transparency and reporting' (recital 9) that organize their practices. They also question whether the key stakeholder in this competition is the right holder, who needs to be able to be 'freely able to choose a CMO' (recital 9) and 'to exercise control over the activities of CMOs' (recital 55). 'CMOs should act', the Directive asserts (recital 22), 'in the best collective interests of the rights holders they represent' (recital 22). It is not obvious that this is the case. It is certainly true that writers such as Joseph Schumpeter (1976/1942) have argued that the best interests of all can be realized through elite competition between their representative organisations, but others have argued to the contrary (Plamenatz, 1977).

\section{Conclusion}

This paper has been concerned with the general question of how a system of regulation, in this case of the copyright regime, might affect creativity and cultural diversity. It has been set against the background of the EU's Digital Single Market, and the prominence this has given to copyright and to the agencies that administer it. But the background also includes the wider question of how markets and government policy affect the possibilities for creativity and cultural diversity, and indeed how the tension between these two goals are part of the larger political process. In attempting to address these complex issues, we focused our attention upon a particular sector of the creative industries (music) and upon a specific intermediary within it (the Collective Management Organisation). 
By way of comparison of the operation of CMOs within Europe, we have shown how these organisations differ in their practices and in the incentives that drive these practices. These differences are revealed, we suggest, in the priority they accord social and cultural activities, as compared to their other responsibilities. It is also revealed in the extent to which cultural diversity features in their agendas.

We then went on to suggest that the EU's current reform of the CMOs is likely to change further the priorities and incentives that operate in the European music market, and that the CMO Directive will have consequences for creativity and cultural diversity.

We cannot claim to have established direct causal links between CMOs and cultural diversity and creativity, or to have definitive evidence of how things may change as a result of EU policy. However, what we have done, we suggest, is to offer a way of analyzing the role of key intermediaries and the impact of regulatory regimes upon them. And insofar as these intermediaries are core components of the creative industries, we have shown how policy directed at them can be seen to re-shape the wider landscape of European music culture.

\section{References}

Alexander, P. (1996) 'Entropy and Popular Culture: Product Diversity in the Popular Music Recording Industry', American Sociological Review, 61(1), pp. 171-4

Arts Council England (nd) 'What is the Creative Case for Diversity?' Available at: http://www.artscouncil.org.uk/media/uploads/pdf/What is the Creative Case for Diversi ty.pdf

Barry, B. (2001) Culture and Equality, Cambridge: Polity

Burkart, P. (2010) Music and Cyberliberties, Middletown: Wesleyan University Press 
Burke, A. (1996) 'How Effective are International Copyright Conventions in the Music Industry?', Journal of Cultural Economics, 20(1), pp. 51-66

Carey, P. (2013) 'The Arts Council vs BPI Debate Gathers Momentum.' Available at:

http://www.huffingtonpost.co.uk/paul-carey/the-arts-council-vs-bpi-

debate b 3353879.html

Christianen, M. (1995) 'Cycles in Symbol Production? A New Model to Explain

Concentration, Diversity, and Innovation in the Music Industry', Popular Music, 14, pp. 55-93

Cloonan, M. and Williamson, J. (2007) 'Rethinking the music industry', Popular Music, 26(2), pp. 305-322

Clydesdale, G. (2006) 'Creativity and Competition: The Beatles', Creativity Research Journal, $18(2)$, pp. $129-39$

Dietz, A. (2014) 'The European Commission's Proposal for a Directive on Collecting Societies and Cultural Diversity - a Missed Opportunity', International Journal of Music Business Research, 3(1), pp. 7-25

Dowd, T. (2004) 'Concentration and Diversity Revisited: Production Logics and the US Mainstream Recording Market, 1940-1990', Social Forces, 82(4), pp. 1411-1455

Dowd, T. and Blyler, M. (2002) 'Charting race: the success of Black performers in the mainstream music market, 1940-1990', Poetics, 30, pp. 87-110

European Commission (2014) Directive on collective management of copyright and related rights and multi-territorial licensing of rights in musical works for online use in the internal market (2014/26/EU)

European Commission (2013) Public Consultation on the Review of EU Copyright Rules, available at: http://ec.europa.eu/internal market/consultations/2013/copyrightrules/index en.htm

European Parliamentary Research Service (2014) 'TTIP and the cultural exception'. Available at: http://epthinktank.eu/2014/08/29/ttip-and-the-cultural-exception/

Ferreira, F. and Waldfogel, J. (2013) ‘Pop Internationalism: Has Half A Century of World Music Trade Displaced Local Culture?', The Economic Journal, 123, pp. 634-664

Fox, M. (2005) 'Market Power in Music Retailing: The Case of Wal-Mart', Popular Music and Society, 28(4), 501-519

Fredriksson, M. (2014) 'Copyright Culture and Pirate Politics', Cultural Studies, 28(5-6), pp. 1022-1047 
Frith, S. (1988) 'The Pleasures of the Hearth - The Making of BBC Light Entertainment', in S. Frith, Music for Pleasure, Cambridge: Polity, pp. 24-44

Frith, S. and Marshall, L. (eds) (2004) Music and Copyright, $2^{\text {nd }}$ Edition, Edinburgh: Edinburgh University Press

Gaines, J. (1991) Contested Culture: The Image, The Voice, And The Law, Chapel Hill: University of North Carolina

Graber (2012) 'Collective Rights Management, Competition Policy and Cultural Diversity: EU Lawmaking at a Crossroads', The WIPO Journal, 4(1), pp. 35-43

Guibault, L. and Van Gompel, S. (2012) 'Collective Management in the European Union', Amsterdam Law School Research Paper, No. 2012-08, available at:

http://papers.ssrn.com/sol3/papers.cfm?abstract_id=1984015

Haunss, S. (2013) 'The changing role of collecting societies in the internet', Internet Policy Review, 2(3), pp. 1-8

Hardy, P. (2012) Download: How the internet transformed the record business, London: Omnibus

Hebdige, D.(1979) Subculture: the Meaning of Style, London: Methuen

Hilty, R. and Nerisson, S. (2013) 'Collective copyright management', in R. Towse and C. Handke (eds), Handbook on the Digital Creative Economy, Cheltenham: Edward Elgar, pp. 222-234

Jones, M. (2012) The Music Industries: From Conception to Consumption, Houndmills: Palgrave Macmillan

Kretschmer, M. (2002) 'Copyright Societies Do Not Administer Individual Rights: The Incoherence of Institutional Traditions in Germany and the UK', in R. Towse (ed.) Copyright in the Cultural Industries, Cheltenham: Edward Elgar, pp.140-64

Kretschmer, M., Klimis, G. and Wallis, R. (1999) 'The Changing Location of Intellectual Property Rights in Music: A Study of Music Publishers, Collecting Societies and Media Conglomerates, Prometheus, 17(2), pp. 163-186

Laing, D. (2004) 'Copyright, Politics and the International Music Industry', in S. Frith and L. Marshall (eds) Music and Copyright, $2^{\text {nd }}$ Edition, Edinburgh: Edinburgh University Press, $p p$. 70-88

Laing, D. (2015/1985) One Chord Wonders. Power and Meaning in Punk Rock, Oakland: PM Press.

Lena, J. (2006) 'Social Context and Musical Content of Rap Music, 1979-1995', Social Forces, 85(1), pp. 479-495 
Lewisohn, M. (2013), The Beatles: Tune In, London: Little, Brown

Looseley, D. (2003) Popular Music in Contemporary France: Authenticity, Politics, Debate, Berg: Oxford

Looseley, D. (1995) The Politics of Fun: Cultural Policy and Debate in Contemporary France, Oxford: Berg

Lopes, P. (1992) 'Innovation and Diversity in the Popular Music Industry, 1969-1990', American Sociological Review, 57(1), pp. 56-71

McLeod, K. and DiCola, P. (2011) Creative License: The Law and Culture of Digital Sampling, Durham: Duke University Press

Nash, K. (2010) Contemporary Political Sociology: Globalization, Politics and Power, Oxford: Wiley-Blackwell

Negus, K. and Pickering, M. (2004) Creativity, Communication and Cultural Value, London: Sage

Negus, K. (1999) Music Genres and Corporate Cultures, London: Sage

Parekh, B. (2000) Rethinking Multiculturalism, Cambridge, MA: Harvard University Press

Peterson, R. (1990) 'Why 1955? Explaining the advent of rock music', Popular Music, 9(1), pp. 97-116

Peterson, R. and Berger, D. (1975) 'Cycles in Symbol Production: The Case of Popular Music', American Sociological Review, 40, pp. 158-173

Peterson, R. and Berger, D. (1996) 'Measuring Industry Concentration, Diversity, and Innovation in Popular Music', American Sociological Review, 61(1), pp. 175-178

Plamenatz, J. (1977) Democracy and Illusion: An Examination of Certain Aspects of Modern Democratic Theory, London: Prentice-Hall

Rochlandet, F. (2003) 'Are Copyright Collecting Societies Efficient? An Evaluation of Collective Administration of Copyright in Europe', in W. J. Gordon and R.Watt (eds.) The Economics of Copyright - Developments in Research and Analysis, Cheltenham: Edward Elgar, pp. 176-98

Ross, P. (2005) 'Cycles in Symbol Production Research: Foundations, Applications, and Future Directions', Popular Music and Society, 28(4), pp. 473-487

Savage, J. (1991) England's Dreaming. Sex Pistols and Punk Rock, London, Faber. 
Schleshinger, P. (2013) 'Expertise, the academy and the governance of cultural policy', Media, Culture and Society, 35(1), pp. 27-35

Schumpeter, J. (1976/1942) Capitalism, Socialism and Democracy, London: George Allen \& Unwin

Stein-Sacks, S. (2012) 'On Quotas as they are found in Broadcasting Music', Canadian Radiotelevision and Telecommunication Commission. Available at:

http://www.crtc.gc.ca/eng/publications/reports/rp12039c.htm

Street, J. (2011) 'The popular, the diverse and the excellent: political values and UK cultural policy', International Journal of Cultural Policy, 17(4), pp. 380-393

Towse, R. (2013) 'The Economic Effects of Digitization on the Administration of Musical Copyrights', Review of Economic Research on Copyright Issues, 10(2), pp. 55-67

Towse, R. (2012) 'Economics of copyright collecting societies and digital rights: is there a case for a centralised digital copyright exchange?', Review of Economic Research on Copyright Issues, 9(2), pp. 31-58

Towse, R. (2006a) 'Copyright and artists: a view from cultural economics', Journal of Economic Surveys, 20(4), pp. 567-585.

Towse, R. (2006b), 'Copyright and Creativity: cultural economics for the $21^{\text {st }}$ century', Review of Economic Research on Copyright Issues, 3(2), pp. 83 -91

Towse, R. (2000a) 'Copyright, Risk and Artists', International Journal of Cultural Policy, 6(1), pp. $91-107$

Towse, R. (2000b) Creativity, Incentive and Reward, Cheltenham, Edward Elgar

Towse, R. (ed) (2002) Copyright in the Cultural Industries, Cheltenham: Edward Elgar

Towse, R. and Handke, C. (eds) (2013) Handbook on the Digital Creative Economy, Cheltenham: Edward Elgar

Toynbee, J. (2000) Making Popular Music: Musicians, Creativity and Institutions, London: Arnold

UK Music (2010) Liberating Creativity, London: UK Music

UNESCO (2005) The 2005 Convention, available at: https://en.unesco.org/creativity/

Waldfogel, J. (2012) 'Copyright Protection, Technological Change, and the Quality of New Products: Evidence from Recorded Music since Napster', Journal of Law and Economics, 55(4), pp. 715-740 
Wallis, R. (2004) 'Copyright and the Composer', in S. Frith and L. Marshall (eds) Music and Copyright, $2^{\text {nd }}$ Edition, Edinburgh: Edinburgh University Press, pp. 103-122

Wallis, R., Baden-Fuller, C., Kretschmer, M. and Klimis, G. (1999) 'Contested Collective Administration of Intellectual Property Rights in Music: The Challenge of the Principles of Reciprocity and Solidarity', European Journal of Communication, 14(1), pp. 5-35

Ward, P. (2013) The Hargreaves Review of Intellectual Property, SN/HA/6430, Westminster: House of Commons Library

Wikstrom, P. (2009) The Music Industry, Cambridge: Polity 